\title{
Antifungal Activity of M. pudica L. Against Selected Human Pathogens
}

\author{
Krishnamurthy Vijayalakshmi and Rajangam Udayakumar \\ Post Graduate and Research Department of Biochemistry, \\ Government Arts College (Autonomous), \\ Kumbakonam - 612 001, Tamil Nadu, India
}

\begin{abstract}
The aim of this study is to determine the antifungal activity of leaf and root extracts of Mimosa pudica against selected fungal pathogens Aspergillus terreus, Aspergillus flavus, Aspergillus niger and Fusarium solani by disc diffusion method. The solvents acetone, aqueous, benzene, diethyl ether and ethanol were used for the preparation of extracts from leaf and root of $M$. pudica. In this study, various concentrations of extracts $2.5 \mathrm{mg} / 50 \mu \mathrm{l}, 3.75$ $\mathrm{mg} / 75 \mu \mathrm{l}$ and $5 \mathrm{mg} / 100 \mu \mathrm{l}$ were used and prepared discs individually for the determination of antifungal activity against selected fungal pathogens. The prepared discs were placed on each petriplate with respective fungal species along with control dimethyl sulfoxide (DMSO) and standard Iitraconazole (30 $\mu \mathrm{g})$ discs and then the plates were incubated at $27^{\circ} \mathrm{C}$ for 72 hrs. After incubation period, the diameter of zones formed around the discs was measured. The maximum levels of zone of inhibition were observed in ethanol root extract against Aspergillus flavus $20 \pm 0.8 \mathrm{~mm}$, Aspergillus terreus $20 \pm 0.7 \mathrm{~mm}$ and acetone root extract against Aspergillus terreus $18 \pm 0.8 \mathrm{~mm}$. The minimum level of zone of inhibition was observed in aqueous leaf extract against Aspergillus terreus $07 \pm 0.4 \mathrm{~mm}$ and acetone leaf extract against Aspergillus niger $07 \pm 0.8 \mathrm{~mm}$. Minimum inhibitory concentration (MIC) of extracts of leaf and root of $M$. pudica against selected fungal species were also determined. In conclusion, there is in need of study to isolate and purify the active phytocompounds from leaf and root of $M$. pudica, which possess antifungal activity against above mentioned fungal species and it may be useful in the treatment of fungal diseases.
\end{abstract}

Keywords: Mimosa pudica, antifungal activity, leaf, root, microorganisms, disc diffusion method.

\section{Introduction}

Infectious diseases represent a critical problem to health and they are one of the main causes of morbidity and mortality worldwide (WHO, 1998). Infectious diseases are caused by fungi, bacteria, viruses and parasites. These are the major threat to public health despite tremendous growth in human chemotherapeutic medicine. Their impact is particularly great in developing countries because of the unavailability of medicines and the emergence of widespread drug resistance (Okeke et al., 2005). Plant diversity serves the humankind as renewable natural resources for a variety of biologically active chemicals. These chemicals bear a variety of properties viz, antibacterial, antifungal, antiviral, anthelmintic, anticancer, sedative, laxative, cardiotonic, diuretic and others (Parajuli et al., 1998). Fungal infections are the leading cause of death in both advanced and developing countries. This is due to the use of immunosuppressive treatments, long term use of antibiotics, and longer survival of immunocompromised individuals (Molero et al., 1998). Fungi are extremely fit for survival as evidenced by their ubiquity in nature. However, of the estimated several hundred thousand species of fungi, fewer than 150-200 were considered to be pathogens of humans. However, in recent years, fungi are flourishing in man. The number of fungi causing systemic disease is growing and the number of systemic diseases caused by fungi is increasing. Up to $7 \%$ patients dying in hospitals have invasive aspergillosis (Groll et al., 1996; Vogesar et al., 1997).

Fungal diseases represent a critical problem to the health, and they are one of the main causes of morbidity and mortality worldwide. Human infections particularly those involving the skin and mucosal surfaces constitute a serious problem especially in tropical and subtropical developing countries (Portillo et al., 2001). The toxic effects of fungi are carcinogenic, genotoxic, nephrotoxic, hepatotoxic, immunosuppressive and cause reproductive disorders (Lacey, 1988; Desjardins et al., 2000; Satish et al., 2007). 
Medicinal plants have been a source of bioactive compounds to treat many diseases. Traditionally used medicinal plants produce a variety of compounds with known therapeutic properties (Chopra et al., 1992). Some bioactive compounds within these plants are responsible for their medicinal value. The most prominent of these bioactive compounds are alkaloids, tannins, flavonoids and phenolic compounds (Shihabudeen et al., 2010). Herbs are widely exploited in the traditional medicine and their curative potentials are well documented (Dubey et al., 2004). Interestingly, plants are widely employed in folk medicine, mainly in communities with inadequate conditions of public health and sanitation. The antimicrobial compounds produced by plants are active against plant and human pathogenic microorganisms (Ramezani et al., 2002).

Due to the emergence of antibiotic resistant human pathogenic fungi, it is of great importance to develop new antifungal agents. The field of ethnobotanical research has expanded greatly in recent years as the value of this type of research in identifying novel therapeutics has come to be more widely recognized (McCutcheon et al., 1992). Several screening studies have been carried out in different parts of the world. There are several reports on the antimicrobial activity of different herbal extracts of different regions of the world (De Boer et al., 2005).

Mimosa pudica Linn. (Family: Mimosaceae) is a famous ornamental plant commonly known as sleeping grass, sensitive plant, humble plant, shy plant, touch-menot, chuimui and lajwanti among other names. Its ornamental use can be attributed to its thigmonastic and seismonastic movements in which closure of leaves and hanging down of petioles takes place in response to certain stimuli like light, vibration, wounds, wind, touch, heat, and cold (Volkov et al., 2010a, b; Soetedjo et al., 2015). This creeping perennial herb has been mentioned as a tribal medicine all over India. Traditionally $M$. pudica is used in the treatment of headache, migraine, insomnia, diarrhea, dysentery, fever, piles and fistula. Roots in the form of decoction are used to treat urinary complaints and in diseases arising from corrupt blood and bile. The paste of the leaves is applied to glandular swelling and dressing for sinus. (Kirtikar and Basu, 1975;Nandkarni et al., 1996; Chopra et al., 1985; Nayagamm and Pushparaj, 1999).

The phenolic extract of root of $M$. pudica is used in the treatment of asthma (Williams and Lemko,
1995). The aqueous extract of stem of $M$. pudica and methanolic extract of leaves and seeds of $M$. pudica showed antimicrobial activity (Ojalla et al., 1999; Ahmad and Beg, 2001; Parrotta, 2001). The methanolic extract of root of $M$. pudica showed very good wound healing activity. The decoction of Mimosa pudica leaves showed anticonvulsant activity (Kannan et al., 2009). There are many pharmacological studies on $M$. pudica, but a few studies are available on antifungal activity of $M$. pudica. There is also lack of study on antifungal activity of leaf and root of $M$. pudica. So, the present study, is focused on antifungal activity of acetone, aqueous, benzene, diethyl ether and ethanol extracts of leaf and root of $M$. pudica was examined against selected fungal species Aspergillus terreus, Aspergillus flavus, Aspergillus niger and Fusarium solani.

\section{Materials and Methods}

\subsection{Collection and preparation of plant material}

The fresh plants of $M$. pudica L. were collected from natural habitats of Thirupanipet Village, Thanjavur District, Tamilnadu, India. The collected plant was identified by Rev. Dr. S. John Britto, Director, Rabinet Herbarium and Centre for Molecular Systematics, St. Joseph's College, Tiruchirappalli, Tamilnadu, India and deposited in the herbarium (Voucher specimen number: KV 001). The collected plants were brought into the laboratory and washed thoroughly in running tap water to remove the soil particles and adhered debris and then finally washed with sterile distilled water. The leaf and root of $M$. pudica were separated and dried under shade for 10 days at room temperature and then the plant materials were pulverized into powder. The powdered materials were stored in air tight containers until the time of use.

\subsection{Preparation of plant extract}

Fifty gram of leaf and root powder of $M$. pudica were soaked in $500 \mathrm{ml}$ of acetone, aqueous, benzene, diethyl ether and ethanol individually and then kept in orbital shaker for $48 \mathrm{~h}$ at room temperature. After $48 \mathrm{~h}$, the mixture was filtered through a clean muslin cloth. Then the filtrate again filtered by using a Whatman No. 1 filter paper and the extracts were concentrated and dried in a rotary evaporator at 37 ${ }^{\circ} \mathrm{C}$ (Ogu et al., 2012) till a sticky mass was obtained. After evaporation of solvents, the dried extracts were stored at $4{ }^{\circ} \mathrm{C}$ until further use. 


\subsection{Disc preparation}

The $6 \mathrm{~mm}$ (diameter) discs were prepared from Whatmann No. 1 filter paper. The discs were sterilized by autoclave at $121{ }^{\circ} \mathrm{C}$. After the sterilization the moisture discs were dried on hot air oven at $50{ }^{\circ} \mathrm{C}$. The different solvent extracts of leaf and root of M. pudica were prepared in dimethyl sulfoxide $(\mathrm{DMSO}, 5 \% \mathrm{w} / \mathrm{v})$. Then various solvent extract discs at different concentrations $(2.5 \mathrm{mg}, 3.75$ $\mathrm{mg}$ and $5 \mathrm{mg}$ ) and control discs were prepared.

\subsection{Microorganisms}

The microorganisms were selected for this study obtained from Microbial Type Culture Collection and Gene Bank (MTCC), Chandigarh, India. The fungal species Aspergillus terreus (MTCC 2207), Aspergillus flavus (MTCC 2501), Aspergillus niger (MTCC 4325) and Fusarium solani (MTCC 2028) were used in this study. The fungal cultures were maintained in Potato Dextrose Agar (PDA) slants at $4{ }^{\circ} \mathrm{C}$.

\subsection{Preparation of microbial suspension culture}

The fungus was grown at $27{ }^{\circ} \mathrm{C}$ on potato dextrose agar (PDA). Spores of the fungus were collected from cultures on agar plates after 7 days as described by Broekaert et al. (1990). The sporangial suspension concentration was estimated using a cell counting chamber and adjusted to $2 \times 10^{6}$ spores $\mathrm{mL}^{-1}$ (Abril et al., 2008). The fungal spore suspensions were stored in $20 \%$ glycerol at $-40{ }^{\circ} \mathrm{C}$.

\subsection{Assay of antifungal activity}

Antifungal activity test was carried out by disc diffusion method originally described by Bauer et al. (1966) with slight modifications. Potato Dextrose Agar (PDA) was prepared and autoclaved at $15 \mathrm{lbs}$ pressure for 20 minutes and cooled to $45{ }^{\circ} \mathrm{C}$. The cooled media was poured on to sterile petriplates and allowed for solidification. The plates with media were seeded with the respective microbial suspension using sterile swab. The various solvents extract discs prepared individually were placed on each petriplate along with control dimethyl sulfoxide (DMSO) and standard Iitraconazole $(30 \mu \mathrm{g})$ discs. The plates were incubated at $27^{\circ} \mathrm{C}$ for $72 \mathrm{hrs}$. After incubation period, the diameter of zone formed around the paper discs were measured and expressed in millimetre $(\mathrm{mm})$. Each experiment was replicated three times.

\subsection{Determination of Minimum Inhibitory Concentration (MIC)}

MIC was determined based on the method of Murray et al. (1995) with slight modifications against selected fungi. The different volumes $20 \mu 1(1 \mathrm{mg})$, $40 \mu \mathrm{l}(1 \mathrm{mg})$ and $60 \mu \mathrm{l}(1 \mathrm{mg})$ of extract $(5 \% \mathrm{w} / \mathrm{v})$ were introduced separately into $10 \mathrm{ml}$ of Potato Dextrose Broth (PDB) medium (v/v). Spore suspension $(10 \mu \mathrm{l})$ of each target fungi was inoculated in the test tube containing PDB and incubated for 3-5 days at $28 \pm 2{ }^{\circ} \mathrm{C}$. The control tubes containing PDB were inoculated only with fungal suspension. Concentration at which no visible growth was observed considered as MIC.

\section{Statistical analysis}

The results of this study were subjected to statistical analysis and expressed as mean \pm standard deviation of three replicates.

\section{Results}

Effect of acetone, aqueous, benzene, diethyl ether and ethanol extracts of leaf and root of $M$. pudica was tested against Aspergillus terreus, Aspergillus flavus, Aspergillus niger and Fusarium solani at different concentrations $2.5 \mathrm{mg}, 3.75 \mathrm{mg}$ and $5 \mathrm{mg}$ by disc diffusion method. The observed results were measured as diameter of zone of inhibition (mm). There was no zone of inhibition in the negative control DMSO. Iitraconazole $(30 \mu \mathrm{g})$ was used as positive control which produced zone of inhibition at different levels against the selected fungal species. The positive control Iitraconazole showed zone of inhibition ranges between $18 \pm 1.4 \mathrm{~mm}$ and $22 \pm 0.9$ $\mathrm{mm}$ against all selected fungal species of this study.

\subsection{Antifungal activity of leaf extracts}

The antifungal activity of acetone, aqueous, benzene, diethyl ether and ethanol extracts of leaf of $M$. pudica was carried out and the results were presented in Table 1. The diethyl ether extract showed highest zone of inhibition against Aspergillus terreus $18 \pm 0.2$ $\mathrm{mm}$ at the concentration of $5 \mathrm{mg}(100 \mu \mathrm{l})$, and the minimum zone of inhibition against against Aspergillus niger $12 \pm 0.4 \mathrm{~mm}$ when compared to other fungal species. The acetone extract showed maximum zone of inhibition against Aspergillus terreus $08 \pm 0.4 \mathrm{~mm}$ and minimum zone of inhibition against Aspergillus niger $07 \pm 0.8 \mathrm{~mm}$. The aqueous extract exhibited antifungal activity by the formation of zone of inhibition against all the selected fungal species only at $5 \mathrm{mg}(100 \mu \mathrm{l})$ of concentration. The benzene extract showed maximum zone of inhibition 
against Aspergillus niger $17 \pm 0.5 \mathrm{~mm}$ and minimum zone of inhibition against Aspergillus terreus $14 \pm 0.6$ $\mathrm{mm}$. The ethanol extract showed maximum zone of inhibition against Fusarium solani $17 \pm 0.4 \mathrm{~mm}$ and minimum zone of inhibition against Aspergillus flavus $14 \pm 0.4 \mathrm{~mm}$. The benzene and ethanol extracts of leaf were also showed antifungal activity against all selected fungal species at both $3.75 \mathrm{mg}(75 \mu \mathrm{l})$ and $5 \mathrm{mg}(100 \mu \mathrm{l})$ of concentrations.

\subsection{Antifungal activity of root extracts}

The antifungal activity of acetone, aqueous, benzene, diethyl ether and ethanol extracts of root of $M$. pudica was also carried out and the results were presented in Table 2. The ethanol extract of root of $M$. pudica showed maximum zone of inhibition against Aspergillus flavus $20 \pm 0.8 \mathrm{~mm}$ in the concentration of $5 \mathrm{mg}$ while the minimum zone of inhibition against Fusarium solani $07 \pm 1.2 \mathrm{~mm}$. The acetone extract exhibited maximum zone of inhibition against Aspergillus terreus $18 \pm 0.8 \mathrm{~mm}$ and minimum zone of inhibition against Aspergillus flavus $15 \pm 0.3 \mathrm{~mm}$. The aqueous extract showed zone of inhibition against Aspergillus niger and Fusarium solani $08 \pm 0.7 \mathrm{~mm}$. The benzene extract showed maximum zone of inhibition against Aspergillus terreus $20 \pm 0.3 \mathrm{~mm}$ but no antifungal activity against Aspergillus niger and Fusarium solani. The diethyl ether extract showed maximum zone of inhibition against Aspergillus terreus $14 \pm 0.5 \mathrm{~mm}$ and minimum zone of inhibition against Fusarium solani $07 \pm 0.4$ $\mathrm{mm}$.

\subsection{Minimum Inhibitory Concentration (MIC) of leaf extracts}

The Minimum Inhibitory Concentration (MIC) of the extract $(5 \% \mathrm{w} / \mathrm{v})$ of leaf of $M$. pudica was determined against selected microorganisms (no visible growth) using $20 \mu \mathrm{l}(1 \mathrm{mg}), 40 \mu \mathrm{l}(2 \mathrm{mg})$ and $60 \mu \mathrm{l}(3 \mathrm{mg})$ of extract in $10 \mathrm{ml}$ of nutrient broth $(\mathrm{v} / \mathrm{v})$ and the results were presented in Table 3 . The acetone extract exhibited MIC of $3 \mathrm{mg}$ or less but more than $2 \mathrm{mg}$ against Fusarium solani, but have no MIC against Aspergillus terreus, Aspergillus flavus and Aspergillus niger in all tested concentrations $1 \mathrm{mg}, 2 \mathrm{mg}$ and $3 \mathrm{mg}$. The aqueous extract of leaf of $M$. pudica has no MIC against selected microorganisms in all tested concentrations. The benzene extract showed MIC of $3 \mathrm{mg}$ or less but more than $2 \mathrm{mg}$ against Aspergillus terreus, Aspergillus niger and Fusarium solani whereas the benzene extract have no MIC against Aspergillus flavus. The diethyl ether extract showed MIC of 2 mg or less but more than $1 \mathrm{mg}$ against Aspergillus terreus and Aspergillus flavus but have no MIC against Aspergillus niger and Fusarium solani. The ethanol extract exhibited MIC of $3 \mathrm{mg}$ or less against Aspergillus terreus and Aspergillus flavus and followed by MIC of $2 \mathrm{mg}$ or less but more than $1 \mathrm{mg}$ against Aspergillus niger and Fusarium solani.

\subsection{Minimum Inhibitory Concentration (MIC) of} root extracts

The MIC of root extract of $M$. pudica against selected microorganisms (no visible growth) was determined using different concentration such as 20 $\mu \mathrm{l}(1 \mathrm{mg}), 40 \mu \mathrm{l}(2 \mathrm{mg})$ and $60 \mu \mathrm{l}(3 \mathrm{mg})$ of extract in $10 \mathrm{ml}$ of nutrient broth $(\mathrm{v} / \mathrm{v})$ and the results were presented in Table 4. The acetone extract showed MIC of $2 \mathrm{mg}$ or less but more than $1 \mathrm{mg}$ against Aspergillus flavus, but have no MIC against Aspergillus terreus, Aspergillus niger and Fusarium solani. The aqueous extract showed MIC of $3 \mathrm{mg}$ or less against Aspergillus flavus but have no MIC against Aspergillus terreus, Aspergillus niger and Fusarium solani. The benzene extract exhibited MIC of $2 \mathrm{mg}$ or less but more than $1 \mathrm{mg}$ against Aspergillus flavus and Aspergillus flavus, whereas have no MIC against Aspergillus niger and Fusarium solani. The diethyl ether extract and ethanol extract showed MIC of $2 \mathrm{mg}$ or less but more than $1 \mathrm{mg}$ against Aspergillus terreus, Aspergillus flavus and Aspergillus niger but have no MIC against Fusarium solani. 
Table 1. Antifungal activity of acetone, aqueous, diethyl ether, ethanol and benzene extracts of leaf of $M$. pudica

\begin{tabular}{|c|c|c|c|c|c|}
\hline \multirow{3}{*}{$\begin{array}{l}\text { Name of solvent } \\
\text { extract }\end{array}$} & \multirow{3}{*}{$\begin{array}{l}\text { Concentration of } \\
\text { plant extract }\end{array}$} & \multicolumn{4}{|c|}{ Diameter of zone of inhibition (mm) } \\
\hline & & \multicolumn{4}{|c|}{ Name of microorgani sm } \\
\hline & & $\begin{array}{l}\text { Aspergillus } \\
\text { terreus }\end{array}$ & $\begin{array}{l}\text { Aspergillus } \\
\text { flavus }\end{array}$ & $\begin{array}{l}\text { Aspergilhus } \\
\text { niger }\end{array}$ & $\begin{array}{l}\text { Fus arium } \\
\text { solani }\end{array}$ \\
\hline DMSO & $\mathrm{NC}$ & - & - & - & - \\
\hline Acetone & $\begin{array}{l}50 \mu 1(2.5 \mathrm{mg}) \\
75 \mu 1(3.75 \mathrm{mg}) \\
100 \mu 1(5 \mathrm{mg})\end{array}$ & $\begin{array}{l}- \\
- \\
08 \pm 0.4\end{array}$ & $\begin{array}{l}- \\
-\end{array}$ & $\begin{array}{l}- \\
- \\
07 \pm 0.8\end{array}$ & $\begin{array}{l}07 \pm 0.1 \\
07 \pm 0.3 \\
08 \pm 0.2\end{array}$ \\
\hline Aqueous & $\begin{array}{l}50 \mu 1(2.5 \mathrm{mg}) \\
75 \mu 1(3.75 \mathrm{mg}) \\
100 \mu 1(5 \mathrm{mg})\end{array}$ & $\begin{array}{l}- \\
- \\
07 \pm 0.4\end{array}$ & $\begin{array}{l}- \\
-\end{array}$ & $\begin{array}{l}- \\
- \\
08 \pm 0.8\end{array}$ & $\begin{array}{l}- \\
- \\
08 \pm 1.2\end{array}$ \\
\hline Benzene & $\begin{array}{l}50 \mu \mathrm{l}(2.5 \mathrm{mg}) \\
75 \mu \mathrm{l}(3.75 \mathrm{mg}) \\
100 \mu 1(5 \mathrm{mg})\end{array}$ & $\begin{array}{l}- \\
14 \pm 0.4 \\
14 \pm 0.6\end{array}$ & $\begin{array}{l}- \\
07 \pm 0.9 \\
15 \pm 0.2\end{array}$ & $\begin{array}{l}08 \pm 0.6 \\
14 \pm 0.6 \\
17 \pm 0.5\end{array}$ & $\begin{array}{l}07 \pm 0.8 \\
14 \pm 1.5 \\
16 \pm 0.8\end{array}$ \\
\hline Diethyl ether & $\begin{array}{l}50 \mu 1(2.5 \mathrm{mg}) \\
75 \mu 1(3.75 \mathrm{mg}) \\
100 \mu 1(5 \mathrm{mg})\end{array}$ & $\begin{array}{l}14 \pm 0.8 \\
14 \pm 0.5 \\
18 \pm 0.2\end{array}$ & $\begin{array}{l}15 \pm 0.8 \\
16 \pm 0.4 \\
16 \pm 0.8\end{array}$ & $\begin{array}{l}- \\
- \\
12 \pm 0.4\end{array}$ & $\begin{array}{l}- \\
- \\
-\end{array}$ \\
\hline Ethanol & $\begin{array}{l}50 \mu 1(2.5 \mathrm{mg}) \\
75 \mu 1(3.75 \mathrm{mg}) \\
100 \mu 1(5 \mathrm{mg})\end{array}$ & $\begin{array}{l}- \\
14 \pm 0.6 \\
16 \pm 0.4\end{array}$ & $\begin{array}{l}- \\
12 \pm 0.7 \\
14 \pm 0.4\end{array}$ & $\begin{array}{l}12 \pm 0.6 \\
14 \pm 0.8 \\
16 \pm 0.7\end{array}$ & $\begin{array}{l}14 \pm 0.5 \\
14 \pm 0.7 \\
17 \pm 0.4\end{array}$ \\
\hline Itra conazole & $\mathrm{PC}(30 \mu \mathrm{g})$ & $22 \pm 0.9$ & $20 \pm 1.2$ & $19 \pm 0.7$ & $18 \pm 1.4$ \\
\hline
\end{tabular}

NC-Negative control (DMSO), PC-Positive control (Itraconazole)

Values are expressed as mean \pm standard deviation of triplicates

Table 2. Antifungal activity of acetone, aqueous, diethyl ether, ethanol and benzene extracts of root of $M$. pudica

\begin{tabular}{|c|c|c|c|c|c|}
\hline \multirow{3}{*}{$\begin{array}{l}\text { Name of solvent } \\
\text { extract }\end{array}$} & \multirow{3}{*}{$\begin{array}{l}\text { Concentration of } \\
\text { plant extract }\end{array}$} & \multicolumn{4}{|c|}{ Diameter of zone of inhibition (mm) } \\
\hline & & \multicolumn{4}{|c|}{ Name of microorganism } \\
\hline & & $\begin{array}{l}\text { Aspergillus } \\
\text { terreus }\end{array}$ & $\begin{array}{l}\text { Aspergillus } \\
\text { flovus }\end{array}$ & $\begin{array}{l}\text { Aspergilhus } \\
\text { niger }\end{array}$ & $\begin{array}{l}\text { Fus arium } \\
\text { solanj }\end{array}$ \\
\hline DMSO & $\mathrm{NC}$ & - & - & - & - \\
\hline \multirow[t]{3}{*}{ Acetone } & $50 \mu 1(2.5 \mathrm{mg})$ & - & $14 \pm 0.5$ & - & - \\
\hline & $75 \mu 1(3.75 \mathrm{mg})$ & - & $14 \pm 1.0$ & - & - \\
\hline & $100 \mu 1(5 \mathrm{mg})$ & $18 \pm 0.8$ & $15 \pm 0.3$ & $16 \pm 0.6$ & $16 \pm 0.6$ \\
\hline \multirow[t]{3}{*}{ Aqueous } & $50 \mu 1(2.5 \mathrm{mg})$ & - & $07 \pm 0.2$ & - & - \\
\hline & $75 \mu 1(3.75 \mathrm{mg})$ & - & $07 \pm 0.4$ & - & - \\
\hline & $100 \mu 1(5 \mathrm{mg})$ & - & $08 \pm 0.5$ & $08 \pm 0.7$ & $08 \pm 0.7$ \\
\hline \multirow[t]{3}{*}{ B enzene } & $50 \mu 1(2.5 \mathrm{mg})$ & $16 \pm 0.2$ & $14 \pm 0.6$ & - & - \\
\hline & $75 \mu 1(3.75 \mathrm{mg})$ & $18 \pm 0.4$ & $16 \pm 0.8$ & - & - \\
\hline & $100 \mu 1(5 \mathrm{mg})$ & $20 \pm 0.3$ & $18 \pm 0.7$ & - & - \\
\hline \multirow[t]{3}{*}{ Diethyl ether } & $50 \mu 1(2.5 \mathrm{mg})$ & $10 \pm 0.9$ & $10 \pm 0.4$ & $10 \pm 0.4$ & - \\
\hline & $75 \mu 1(3.75 \mathrm{mg})$ & $12 \pm 0.6$ & $10 \pm 0.8$ & $10 \pm 1.0$ & - \\
\hline & $100 \mu 1(5 \mathrm{mg})$ & $14 \pm 0.5$ & $12 \pm 0.9$ & $12 \pm 0.6$ & $07 \pm 0.4$ \\
\hline \multirow[t]{3}{*}{ Ethanol } & $50 \mu 1(2.5 \mathrm{mg})$ & $18 \pm 0.4$ & $16 \pm 0.4$ & $14 \pm 0.7$ & - \\
\hline & $75 \mu \mathrm{l}(3.75 \mathrm{mg})$ & $18 \pm 0.8$ & $16 \pm 0.7$ & $14 \pm 1.1$ & - \\
\hline & $100 \mu 1(5 \mathrm{mg})$ & $20 \pm 0.7$ & $20 \pm 0.8$ & $16 \pm 0.5$ & $07 \pm 1.2$ \\
\hline Itraconazole & $\mathrm{PC}(30 \mu \mathrm{g})$ & $22 \pm 0.9$ & $20 \pm 1.2$ & $19 \pm 0.7$ & $18 \pm 1.4$ \\
\hline
\end{tabular}

NC-Negative control (DMSO, PC-Positive control (Itraconazole)

Values are expressed as mean \pm standard deviation of triplicates 
Table 3: Minimum Inhibitory Concentration (MIC) of leaf extract of $M$. pudica against selected microorganisms

\begin{tabular}{|c|c|c|c|c|c|}
\hline \multirow{2}{*}{$\begin{array}{l}\text { Name of } \\
\text { solvent extract }\end{array}$} & \multirow{2}{*}{$\begin{array}{l}\text { Concentration } \\
\text { of plant extract in } 10 \mathrm{ml} \\
\text { of broth (mg) }\end{array}$} & \multicolumn{4}{|c|}{ Appearance of growth of microorganisms } \\
\hline & & $\begin{array}{c}\text { Aspergilhus } \\
\text { terreus }\end{array}$ & $\begin{array}{l}\text { Aspergillus } \\
\text { fiavis }\end{array}$ & $\begin{array}{c}\text { As pergillus } \\
\text { niger }\end{array}$ & $\begin{array}{c}\text { Fusarium } \\
\text { solani }\end{array}$ \\
\hline \multirow[t]{2}{*}{ Control } & - & + & + & + & + \\
\hline & $20 \mu 1(1 \mathrm{mg})$ & + & + & + & + \\
\hline \multirow[t]{3}{*}{ Acetone } & $40 \mu 1(2 \mathrm{mg})$ & + & + & + & + \\
\hline & $60 \mu 1(3 \mathrm{mg})$ & + & + & + & - \\
\hline & $20 \mu 1(1 \mathrm{mg})$ & + & + & + & + \\
\hline \multirow[t]{3}{*}{ Aqueous } & $40 \mu 1(2 \mathrm{mg})$ & + & + & + & + \\
\hline & $60 \mu 1(3 \mathrm{mg})$ & + & + & + & + \\
\hline & $20 \mu 1(1 \mathrm{mg})$ & + & + & + & + \\
\hline \multirow[t]{3}{*}{ Benzene } & $40 \mu 1(2 \mathrm{mg})$ & + & + & + & + \\
\hline & $60 \mu 1(3 \mathrm{mg})$ & - & + & - & - \\
\hline & $20 \mu 1(1 \mathrm{mg})$ & + & + & + & + \\
\hline \multirow[t]{3}{*}{ Diethyl ether } & $40 \mu 1(2 \mathrm{mg})$ & - & - & + & + \\
\hline & $60 \mu 1(3 \mathrm{mg})$ & - & - & + & + \\
\hline & $20 \mu 1(1 \mathrm{mg})$ & + & + & + & + \\
\hline \multirow[t]{2}{*}{ Ethanol } & $40 \mu 1(2 \mathrm{mg})$ & + & + & - & - \\
\hline & $60 \mu 1(3 \mathrm{mg})$ & - & - & - & - \\
\hline
\end{tabular}

+ Appearance of visible growth of fungus (turbid tube)

- No appearance of visible growth of fungus (clear tube)

Table 4: Minimum Inhibitory Concentration (MIC) of root extract of $M$. pudica against selected microorganisms

\begin{tabular}{|c|c|c|c|c|c|}
\hline \multirow{2}{*}{$\begin{array}{l}\text { Name of } \\
\text { solvent extract }\end{array}$} & \multirow{2}{*}{$\begin{array}{l}\text { Concentration } \\
\text { of plant extract in } 10 \mathrm{ml} \\
\text { of broth }(\mathrm{mg})\end{array}$} & \multicolumn{4}{|c|}{ Appearance of growth of microorganisms } \\
\hline & & $\begin{array}{c}\text { Aspergillus } \\
\text { terreus }\end{array}$ & $\begin{array}{c}\text { Aspergillus } \\
\text { fiavis }\end{array}$ & $\begin{array}{l}\text { Aspergillus } \\
\text { niger }\end{array}$ & $\begin{array}{l}\text { Fusarium } \\
\text { solani }\end{array}$ \\
\hline \multirow[t]{2}{*}{ Control } & - & + & + & + & + \\
\hline & $20 \mu 1(1 \mathrm{mg})$ & + & + & + & + \\
\hline \multirow[t]{3}{*}{ Acetone } & $40 \mu 1(2 \mathrm{mg})$ & + & - & + & + \\
\hline & $60 \mu 1(3 \mathrm{mg})$ & + & - & + & + \\
\hline & $20 \mu 1(1 \mathrm{mg})$ & + & + & + & + \\
\hline \multirow[t]{3}{*}{ Aqueous } & $40 \mu 1(2 \mathrm{mg})$ & + & + & + & + \\
\hline & $60 \mu 1(3 \mathrm{mg})$ & + & - & + & + \\
\hline & $20 \mu 1(1 \mathrm{mg})$ & + & + & + & + \\
\hline \multirow[t]{3}{*}{ Benzene } & $40 \mu 1(2 \mathrm{mg})$ & - & - & + & + \\
\hline & $60 \mu 1(3 \mathrm{mg})$ & - & - & + & + \\
\hline & $20 \mu 1(1 \mathrm{mg})$ & + & + & + & + \\
\hline \multirow[t]{3}{*}{ Diethyl ether } & $40 \mu 1(2 \mathrm{mg})$ & - & - & - & + \\
\hline & $60 \mu 1(3 \mathrm{mg})$ & - & - & - & + \\
\hline & $20 \mu 1(1 \mathrm{mg})$ & + & + & + & + \\
\hline Ethanol & $40 \mu 1(2 \mathrm{mg})$ & - & - & - & + \\
\hline
\end{tabular}

$+\quad$ Appearance of visible growth of fungus (turbid tube)

- No appearance of visible growth of fungus (clear tube) 


\section{Discussion}

Infections by pathogenic fungi are increasingly recognized as an emerging threat to public health (Wu, 1994; Walsh et al., 1996). These problems are associated with resistance to antibiotics and toxicity during prolonged treatment with several antifungal drugs (Giordani et al., 2001). Due to this emergence of antibiotic resistant pathogenic fungi, it is of great importance to develop new antifungal agents. The field of ethnobotanical research has expanded greatly in recent years as the value of this type of research in identifying novel therapeutics has come to be more widely recognized (McCutcheon et al., 1992). Medicinal plants are of great importance to health of individuals and communities. This importance lies in their chemical substances that produce a definite physiological action on the human body. The most important of these bioactive compounds include alkaloids, tannins, flavonoids, and phenolic compounds (Edeoga et al., 2005). In the present study, various solvent extracts of leaf and root of $M$. pudica showed antifungal activity against Aspergillus terreus, Aspergillus flavus, Aspergillus niger and Fusarium solani. The benzene and ethanol extract of leaf of $M$. pudica showed zone of inhibition against all selected fungal species. The acetone and aqueous extracts of leaf showed no antifungal activity against Aspergillus flavus and showed zone of inhibition against Aspergillus terreus and Aspergillus niger at $5 \mathrm{mg}$ of concentration. The diethyl ether extract of leaf showed no antifungal activity against Fusarium solani.

In the present study, the antifungal activity of different solvent extracts of root of $M$. pudica was exhibited as different level of zone of inhibition against selected fungal species. The acetone and benzene extract of root of $M$. pudica showed no activity against Aspergillus niger and Fusarium solani. The diethyl ether and ethanol extract of root showed activity against Fusarium solani at $5 \mathrm{mg}$ of concentration. The aqueous extract of root showed no activity against Aspergillus terreus.

Fungicidal effect of medicinal plants may be due to the lysis of fungal cell wall and cytoplasmic membrane due to the liberation of antimicrobial products and it was also reported that plant lytic enzymes act on the fungal cell used in traditional medicine. The cell wall of fungi undergoes breakage caused by the hydrolysis of 1,3 glycan, 1,6, glycan and chitin polymer (Paula et al., 2006).

The present study is also in agreement with the earlier study, in that the antifungal activity of methanol extract of leaf of Euphorbia hirta against Candida albicans was reported (Basma et al., 2011). The antifungal activity of different solvent extracts of leaf and flower of Withania somnifera was reported (Singariya et al., 2012). Similarly, the antifungal activity of aqueous, alcoholic and ethyl acetate extracts of leaves of five Terminalia species against plant pathogenic fungi A. flavus, A. niger, Alternaria brassicicola, A. alternate and Helminthosporium tetramera was reported (Saheb et al., 2011). Antifungal activity of organic extracts of leaf, flower and fruit of Lawsonia inermis against Aspergillus niger, Penicillium notatum, Fusarium oxysporum, Colletotrichum gloeosporioides and Rhizopus stolonifer was reported (Jeyaseelan et al., 2012). M. pudica was attributed to the presence of bioactive constituents like terpenoids, flavonoids, glycosides, alkaloids, quinines, phenols, tannins, saponins and coumarins and they may be responsible for the antimicrobial activity (Gandhiraja et al., 2009).

\section{Conclusion}

In this study, the antifungal activitiy of acetone, aqueous, benzene, diethyl ether and ethanol extracts of leaf and root of M. pudica was confirmed against selected fungal species Aspergillus terreus, Aspergillus flavus, Aspergillus niger and Fusarium solani. Antimicrobial properties of medicinal plant $M$. pudica may be due to the presence of bioactive compounds. The further study is needed to find out the bioactive compounds, which are responsible for antifungal activity. So, the identification of phytocompound with antifungal activity in leaf and root of $M$. pudica, may be useful in the preparation of drugs for the treatment of fungal diseases.

\section{References}

[1] Abril M, Curry KJ, Smith BJ and Wedge DE, Improved microassays used to test natural productbased and conventional fungicides on plant pathogenic fungi. Plant Disease 92:106-112 (2008).

[2] Ahmad I and AZ Beg, Antimicrobial and phytochemical studies on 45 Indian medicinal plants against multi-drug resistant human pathogens. Journal Ethnopharmacology, 74: 113-23 (2001).

[3] Basma AA, Zuraini Z and Sasidharan S, A transmission electron microscopy study of the diversity of Candida albicans cells induced by Euphorbia hirta L. leaf extract in vitro. Asian Pac J Trop Biomed, 1(1): 2022 (2011).

[4] Broekaert WF, Cammue BPA, De Bolle MFC, Thevissen K, De Samblanx GW and 
Osborn R.W, Antimicrobial peptides from plants. Critical Reviews in Plant Sciences 16:297-323, (1997).

[5] Chopra RN, Chopra IC, Handa KL and Kapur LD, Indigenous Drugs of India, 2nd edn. Academic Publisher, Calcutta, 234, (1985).

[6] Chopra RN, Nayer SL and Chopra IC: Glossary of Indian Medicinal Plants. 3 edition. New Delhi: Council of Scientific and Industrial Research, ISBN, 7-246 (1992).

[7] De Boer HJ, Kool A, Broberg A. Mziray WR, Hedberg I and Levenfors JJ, Antifungal and antibacterial activity of some herbal remedies from Tanzania. $J$ Ethnopharm, 96: 461-469 (2005).

[8] Desjardins AE, Manandhar G, Plattner RD, Maragos CM, Shrestha K and McCormick SP, Occurrence of Fusarium species and mycotoxins in Nepalese Maize and Wheat and the effect traditional processing method on mycotoxin levels. Journal of Agricultural and Food Chemistry, 48:137783 (2000).

[9] Dubey NK, Kumar R, and Tripathi P, Global promotion of herbal medicines: India's opportunity. Current Science, 86: 37-41(2004).

[10] Edeoga HO, Okwu DE and Mbaebie BO, Phytochemical constituents of some Nigerian medicinal plants. Afric. J. Biotech. 4, 685-688, (2005).

[11] Giordani R, Trebaux J, Masi M and Regli $P$, Enhanced antifungal activity of ketoconazole by Euphorbia characias latex against Candida albicans. J Ethnopharmacol 78:1-5, (2001).

[12] Groll AH, Shah PM, Mentzel C, Schneider M, Just-Nuebling G and Huebner $\mathrm{K}$, Trends in the postmortem epidemiology of fungal infections at a University hospital. J Infect, 33:23-32 (1996).

[13] Jeyaseelan EC, Vinuja T, Pathmanathan K and Jeyadevan JP, Control of plantn pathogenic fungi using organic solvent extracts of leaf, flower and fruit of Lawsonia inermis L. International Journal of Pharmaceutical and Biological Archives 3(4): 783-788 (2012).

[14] Kannan S, Aravinth VJS, SamJeeva KE, Saminathan E, Suthakaran R, Ravi Kumar $\mathrm{M}$, and Parimala DB. Wound healing activity of Mimosa pudica Linn formulation. International Journal of
PharmTech Research, 1(4): 1554-1558, (2009).

[15] Kirtikar KR and Basu BD, Indian Medicinal Plants, vol. 3, 2nd edn. Bishen Singh Mahendra Pal Singh, Dehra Dun, 2344, (1975).

[16] Lacey J, The microbiology of cereal grains from areas of Iran with a high incidence of oesophageal cancer. Journal of Stored Product Research, 24:39-50 (1988).

[17] McCutcheon AR, Ellis SM, Hancock REW and Towers GNH, Antibiotic screening of medicinal plants of the British Columbian native peoples. J Ethnopharmacol, 37: 213-23 (1992).

[18] Molero G, Orejas RD, Garcia FN, Monteoliva L, Pla J, Gil C, Parez MS and Nombela C, Internation. Microbiol, 1, 95106, (1998).

[19] Nandkarni KM, Nandkarni AK and Chopra RN, Indian Materia Medica, vol.1, Popular Prakashan, Bombay, 500 (1996).

[20] Nayagam, MC and Pushparaj MS, J Econ Taxon Botany. 23: 417-20 (1999).

[21] Ogu GI, Williams TO, Nwachukwu PU and Igere $\mathrm{BE}$, Antimicrobial and phytochemical evaluation of the leaf, stem bark and root extracts of Cyathula prostrata (L) blume against some human pathogens. J Intercult Ethnopharmacol 1(1): 35-43 (2012).

[22] Ojalla T, Remes $\mathrm{S}$ and Hans $\mathrm{P}$, Antimicrobial activity of some coumarin containing herbal plants growing in Finland. Journal Ethnopharmacology, 68(1-3): 267274, (1999).

[23] Okeke IN, Laxminarayan R, Bhutta ZA, Duse AG, Jenkins P, O’Brien TF, et al., Antimicrobial Resistance in developing countries. Part 1: recent trends and current status. Lancet Infect Dis 5, 481-493, (2005).

[24] Parajuli DP, Gyawali AR, and Shrestha BM, A Manual of the Important NonTimber Forest Products in Nepal. Training and manpower development in C.F.M. Pokhara, Nepal, (1998).

[25] Parrotta JA, Healing Plants of Peninsular India,CABI publishing USA, pp: 557, (2001).

[26] Paula CR, Krebs VL, Auler ME, Ruiz LS, Matsumoto FE and Silva EH et. al., Nosocomial infection in newborns by Pichia anomala in a Brazilian intensive care unit. Med Mycol, 44(5):479-84, (2006). 
[27] Portillo A, Vila R, Freixa B, Adzet T, and Cañigueral S, Antifungal activity of Paraguayan plants used in traditional medicine. J Ethnopharmacol, 76:93-8 (2001).

[28] Ramezani H, Singh HP, Batish DR Kohli and Dargan JS, Fungicidal effect of volatile oils from Eucalyptus citriodora and its major constituent citronetial. New Zealand plant protection, 55: 327-330 (2002).

[29] Saheb SL, More Sm, Junne SB and Wadje SS. The antifungal activity of five Terminalia species checked by paper disc method. International Journal of Pharma Research and Development, 3(2): 36-40 (2011).

[30] Satish S, Mohana DC, Ranhavendra MP and Raveesha KA, Antifungal activity of some plant extracts against important seed borne pathogens of Aspergillus sp. Journal of Agricultural Technology, 3(1):109-19 (2007).

[31] Shihabudeen MH, Priscilla DH and Thirumurugan K, Antimicrobial activity and phytochemical analysis of selected Indian folk medicinal plants. Int J Pharma Sci Res, 1: 430-434 (2010).

[32] Singariya P, Kumar P, Mourya KK, Estimation and bio activity of aerial parts of Withania somnifera against the bacterial and fungal microbes. Int J Pharm Pharm Sci, 4: 553-557 (2012).

[33] Soetedjo H, Haryadi B and Taspyanto D, Effect of light Illumination on leaves movement of Mimosa pudica. Appl Mech Mater, 771: 63-7 (2015).

[34] Vogesar M, Hass A, Aust D and Ruckdeschel G, Postmortem analysis of invasive aspergillosis in a tertiary care hospital. Eur J Clin Microbiol Inf Dis, 16:16 (1997).

[35] Volkov AG, Foster JC and Markin VS, Signal transduction in Mimosa pudica: biologically closed electrical circuits. Plant Cell Environ, 33:816-27, (2010).

[36] Volkov AG, Foster JC, Baker KD and Markin VS, Mechanical and electrical anisotropy in Mimosa pudica pulvini. Plant Signal Behav 5(10):1211-21 (2010).

[37] Walsh TJ, Gonzalez C, Lyman CA, Chanock SJ and Pizzo PA, Invasive fungal infections in children: recent advances in diagnosis and treatment. Adv Pediatr Infect Dis 11:187-290, (1996).

[38] Williams D and TL Lemko, Foye's, Principles of MedicinalChemistry, 5th Edn Lippincott Williams and Wilkins Publication, 633 (1995).

[39] World Health Organization, The World Health report. Life in the 21st century: a vision for all, 2 Measuring health. World Health Organization, Geneva, Switzerland, 39-60Wu TC, On the development of antifungal agents: perspective of the US Food and Drug Administration. Clin Infect Dis 19:S54-S58,

(1994). 